\title{
Immunocytochemical Characterization of AMPA-Selective Glutamate Receptor Subunits: Laminar and Compartmental Distribution in Macaque Striate Cortex
}

\author{
Renee K. Carder \\ Zanvyl Krieger Mind/Brain Institute, Johns Hopkins University, Baltimore, Maryland 21218
}

Subunit proteins that comprise functional AMPA receptors were localized by immunocytochemical methods in the adult macaque primary visual cortex (V1). GluR1, GluR2/3/4c, and GluR4 immunoreactivity consisted of rich plexuses of punctate profiles scattered throughout the neuropil, in radial arrays, and outlining the membrane of somata and proximal dendrites. Cytoplasmic immunoreactivity was limited. GluR2/3/4c immunostaining was more prominent along the somata surface and exhibited greater levels of cytoplasmic immunoreactivity than GluR1 and GluR4 immunostaining. The density of AMPA subunit immunoreactive elements also varied across layers and compartments of macaque V1. Immunoreactivity for GluR1, GluR2/3/4c, and GluR4 was densest in three bands that corresponded to layers IVA, IVC, and VI. Immunostaining for each subunit was also unevenly distributed within many of the layers.
In layers II-III, patches of intense immunostaining coincided with cytochrome oxidase (CO)-rich blobs. In layer IVA, intense subunit staining formed a conspicuous honeycomb pattern. In layer IVC, subunit staining formed a radial lattice. GluR2/3/4c subunit immunostaining was also preferentially distributed within the CO-rich blobs of layers $\mathrm{V}-\mathrm{VI}$. These findings demonstrate that AMPA subunit immunoreactivity is densely concentrated in layers and compartments receiving direct geniculocortical innervation. This distribution, which differs from that of excitatory synapses, suggests that the density of AMPA receptors is unevenly distributed at synaptic and possibly extrasynaptic sites within macaque visual circuits.

Key words: V1; area 17; glutamate; excitatory neurotransmission; geniculocortical afferents; cytochrome oxidase blobs
Primary visual cortical circuits use excitatory, chemically mediated synaptic signals for transmitting and generating the wide variety of functional properties required for sensory analysis (Streit, 1984; Tsumoto, 1990; Carder and Hendry, 1994). Geniculocortical afferents form three parallel, but largely separate, routes through which information from the retina is passed via the dorsal lateral geniculate nucleus to the primary visual cortex (V1) (Blasdel and Lund, 1983; Freund et al., 1989; Hendry and Yoshioka, 1994). Excitatory activity arriving through each of the thalamic pathways is integrated with the activity of a series of layer-specific cortical connections that progressively transform and relay visual information. The majority of these intrinsic circuits are also excitatory, accounting for $75-85 \%$ of the total synaptic connections any single neuron receives (Beaulieu et al., 1992). Thus, input to cortical cells is primarily excitatory and comes not only from a patterned thalamic input, but from a massive convergent input from other excitatory cortical cells.

Clearly, each excitatory input is likely to have a different role in shaping the response properties of a neuron. How a neuron integrates incoming signals will depend not only on the cellular geometry and intrinsic membrane properties of the cell, but also on the shape and size of the synaptic current. The excitatory neurotransmitter glutamate can act through a variety of postsyn-

Received Sept. 16, 1996; revised Jan. 21, 1997; accepted Feb. 19, 1997.

I thank Priya Swamy and Dana Yoo for technical assistance, Dr. Stewart Hendry for providing the monkey material, and Drs. David Calkins, Stewart Hendry, Lucia Galli-Resta, and Michael Steinmetz for valuable criticism of this manuscript.

Correspondence should be addressed to Renee K. Carder, Department of Neurology MC 2030, University of Chicago, 5841 South Maryland Avenue, Chicago, IL 60637.

Copyright (C) 1997 Society for Neuroscience $\quad 0270-6474 / 97 / 173352-12 \$ 05.00 / 0$ aptic receptors, including the cation-specific ion channels; AMPA, NMDA, and kainate receptors; and G-protein-coupled metabotropic glutamate receptors (Collingridge and Lester, 1989; Monaghan et al., 1989; Schoepp et al., 1990). Multiple classes of excitatory receptors can be activated at a given synapse with significant variations in the contribution of each class (Huettner and Baughman, 1988; Bekkers and Stevens, 1989; Jones and Baughman, 1991; Stern et al., 1992). Even at synapses using the same receptor class, the physiological properties are not necessarily equivalent (Colquhoun et al., 1992; Stern et al., 1992; Hestrin, 1993; Livsey et al., 1993; Koh et al., 1995). The recent identification of families of genes coding for glutamate receptor subunit proteins has revealed that each receptor family is composed of subunits that can assemble in various combinations to form ligand-gated channels with unique pharmacological, kinetic, and gating characteristics (Hollmann et al., 1989, 1991; Keinänen et al., 1990; Nakanishi et al., 1990). Variations in the receptor classes and subtypes expressed, their densities, and their placement are likely to influence how a neuron integrates a particular incoming signal.

As an initial step in understanding the relationship between glutamate receptor expression and synaptic communication in different parts of the visual cortical circuit, the present study examined the distribution of AMPA receptors in macaque V1. AMPA receptors are endowed with kinetic properties that allow them to transmit fast repetitive signals and are therefore used at most glutamatergic synapses in the vertebrate CNS (Collingridge and Lester, 1989). Using AMPA subunit immunoreactivity as a marker, one potentially specific for AMPA receptors, the present study reports that rich plexuses of punctate profiles immunoreactive for each of the subunits were unevenly distributed across layer 

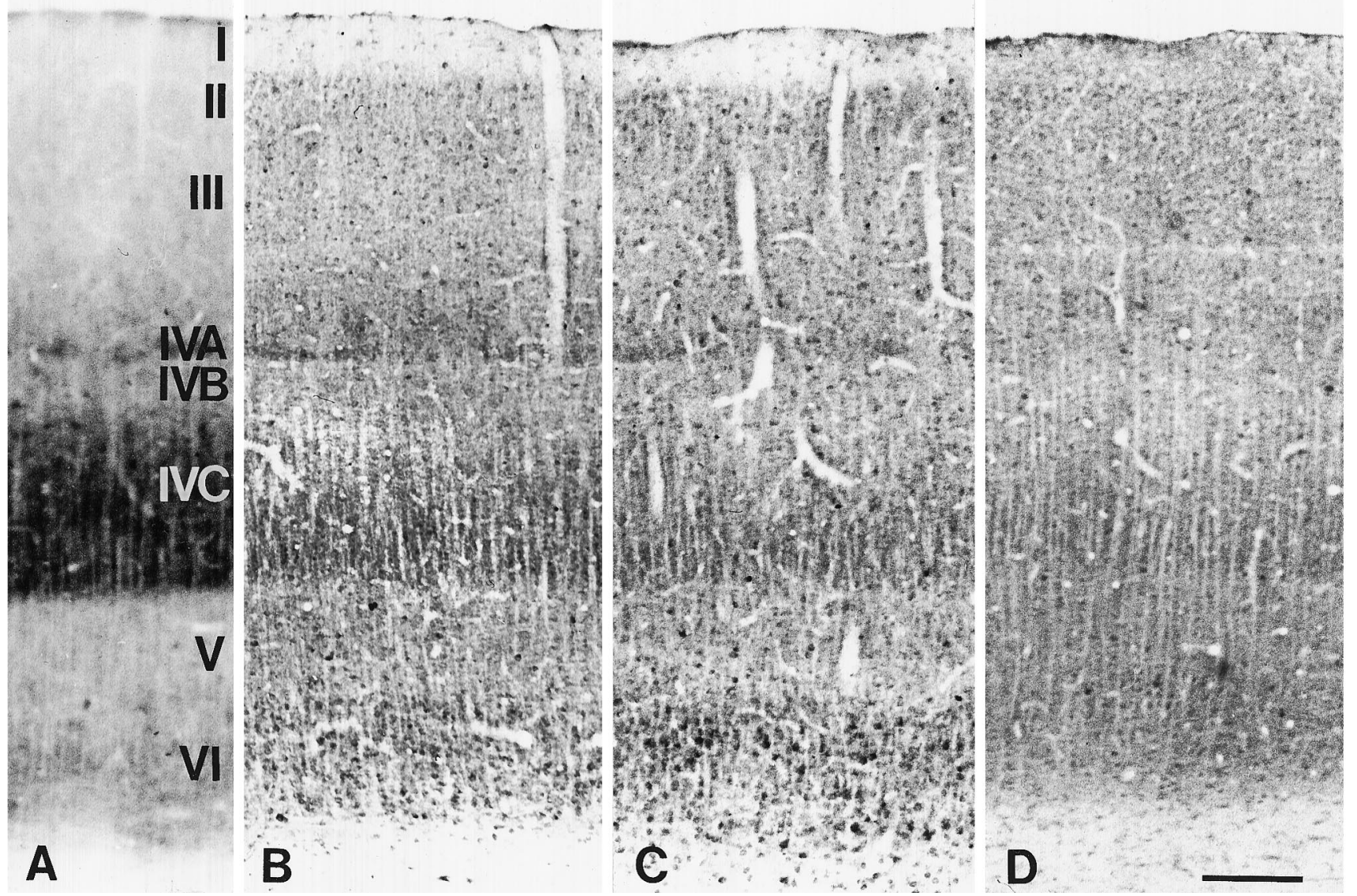

Figure 1. Laminar distribution of AMPA subunit immunoreactivity in sagittal sections through adult macaque primary visual cortex. $A$, Section stained histochemically for $\mathrm{CO}$. The characteristic pattern of staining was used to determine the laminar borders in adjacent immunostained sections. $B-D$, Photomicrographs of sections immunostained for GluR1 $(B)$, GluR2/3/4c $(C)$, and GluR4 $(D)$. All sections are most intensely stained in layers IVC and VI. Enhanced staining is present in layer IVA in sections processed for each of the subunits, but is relatively difficult to detect in GluR4-immunostained sections cut along radial lines. Scale bar, $200 \mu \mathrm{m}$.

and compartments of macaque V1. Implications of this subunit organization are discussed.

\section{MATERIALS AND METHODS}

Ten normal adult monkeys (Macaca fascicularis) were used in this study. All animals were killed with an overdose of Nembutal, followed by perfusion through the heart with $2-4 \%$ paraformaldehyde and $0-0.1 \%$ glutaraldehyde in $0.1 \mathrm{M}$ phosphate buffer. The occipital lobes from each monkey were cut into sagittal blocks that included V1. Blocks were sunk in $20-30 \%$ sucrose/phosphate buffer solution at $4^{\circ} \mathrm{C}$.

Sections were cut serially on a sliding microtome. Some blocks of occipital cortex were cut sagittally. Others were flattened while freezing and were cut parallel to the opercular surface of the occipital lobe. Sections of varying thickness were cut and processed (alternating 15 and $30 \mu \mathrm{m}$ or 20 and $40 \mu \mathrm{m}$ ). The thicker sections in each series were reacted histochemically for cytochrome oxidase (CO) (Wong-Riley, 1979) or stained with thionin. Thinner sections were processed immunocytochemically for AMPA-selective subunits with commercially available rabbit antisera directed against synthetic peptides corresponding to C-terminal sequences of GluR1 (KMSHSSGMPLGATGL), GluR2/3/4c (KQNFATYKEGYNVGIESVKI), and GluR4 (KHTGTAIRQSSGLAVIASDLP) (Chemicon, Temecula, CA, and Upstate Biotechnology, Lake Placid, NY). Because these antibodies have been raised against peptides near the carboxyl termini, they recognize both the flip and flop versions of the GluR subunits. The characterization and immunocytochemical application of these antibodies has been reported by Wenthold et al. (1992), Petralia and Wenthold (1992), and Martin et al. (1993a,b). A wide range of dilutions were tested for each. Sections were preincubated in $0-0.05 \%$ Triton X-100 and 3-10\% normal serum in $0.1 \mathrm{~m}$ phosphate buffer (dilution buffer). In some cases, $1 \%$ nonfat dried milk was added to the dilution buffer. After 3-5 hr, sections were transferred to a solution containing the primary antibody and $3-10 \%$ normal serum in $0.1 \mathrm{M}$ phosphate buffer and incubated for $48-72 \mathrm{hr}$ at $4^{\circ} \mathrm{C}$. Subsequently, the sections were processed by the avidin-biotin-peroxidase method (Vector Laboratories, Burlingame, CA; Sigma ImmunoChemicals, St. Louis, MO) or the peroxidase anti-peroxidase method (DAKO, Carpinteria, CA) and reacted in 3,3'-diaminobenzidine tetrahydrochloride and hydrogen peroxidase. Some immunostained sections were osmicated. Sections in which the normal rabbit serum (1:1000) was substituted for the primary antisera or the primary antisera was omitted served as controls. No signal was produced with these procedures.

\section{RESULTS}

\section{Laminar distribution}

Immunoreactivity for the GluR1, GluR2/3/4c, and GluR4 subunits was present throughout the thickness of macaque V1. The intensity of immunostaining varied across layers, forming three bands that contained high levels of immunoreactivity, three bands that formed intermediate levels of immunoreactivity, and one band that contained a low level of immunoreactivity (Fig. 1). When compared with the pattern of $\mathrm{CO}$ (Fig. 1A) in adjacent sections, the dense bands were determined to include layers IVA, IVC, and VI; the intermediate bands II-III, IVB, and V; and the low band layer I.

Immunoreactivity for each of the subunits was located predominantly in the neuropil and consisted of a rich plexus of punctate profiles (Fig. 2). Most of the immunostained profiles were small 

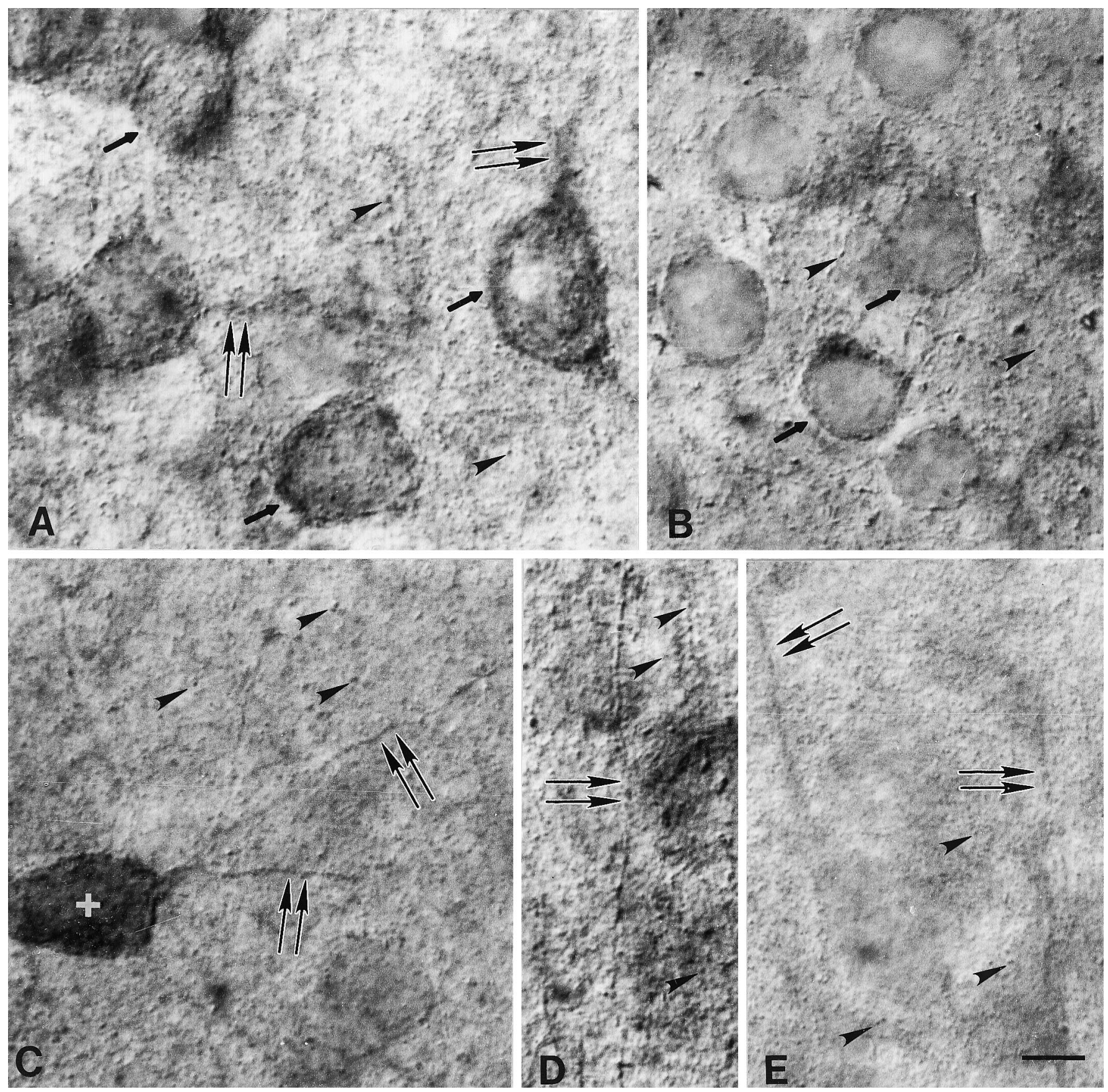

Figure 2. Details of AMPA subunit immunoreactivity in macaque primary visual cortex. $A-C$, Discrete puncta (arrowheads) of GluR2/3/4c immunostaining occupy layers II-III $(A)$, IVC $(B)$, and I $(C)$. The puncta vary in size and density with each layer. In addition to being scattered throughout the neuropil, immunostained puncta tend to outline the peripheries of unstained somata (arrows) and proximal dendrites (double arrows). In some cases, intracellular reaction product (white cross) is also apparent $(C)$. $D-E$, Immunostaining for GluR1 $(D)$ subunit at the border between layers V and VI and GluR4 $(E)$ in layers II-III. Immunostaining for both of these subunits includes discrete puncta scattered throughout the neuropil (arrows) and puncta outlining select vertical fibers (double arrows). Scale bar, $10 \mu \mathrm{m}$.

circular elements, less than $1 \mu \mathrm{m}$ in diameter, but some were larger and irregularly shaped. Immunoreactive elements were scattered throughout the neuropil (Fig. 2) but were also frequently found in radial clusters, along the length of apical dendrites (Fig. 2D,E), and surrounding the somata and proximal processes of neurons (Fig. $2 A-C$ ). Some cells displayed cytoplasmic immunoreactivity (Fig. 2C). GluR2/3/4c immunostaining associated with the cell surface and/or cytoplasm was always greater than that found with GluR1 or GluR4 immunostaining.
The density of different immunostained elements varied throughout the layers of V1. In supragranular layers, GluR1 and GluR2/3/4c immunostaining consisted of scattered fine and coarse puncta, and dense immunostaining surrounding the somata of neurons. GluR2/3/4c immunostaining differed from that of GluR1 staining in that coarse puncta were more evident and a greater number of somata displayed immunoreactive puncta along their surface (Fig. $3 A, B$ ). Immunoreactivity for GluR4 consisted of fine puncta scattered throughout the neu- 
ropil, and along the surface of a limited number of pyramidal neurons and apical dendrites (Fig. $3 C$ ). In layer IVC, immunostaining for GluR1, GluR2/3/4c, and GluR4 consisted of a radial lattice in which immunostained puncta formed a meshwork of small radial clusters separated by unstained regions (Fig. 4). In general, immunostaining associated with the cell
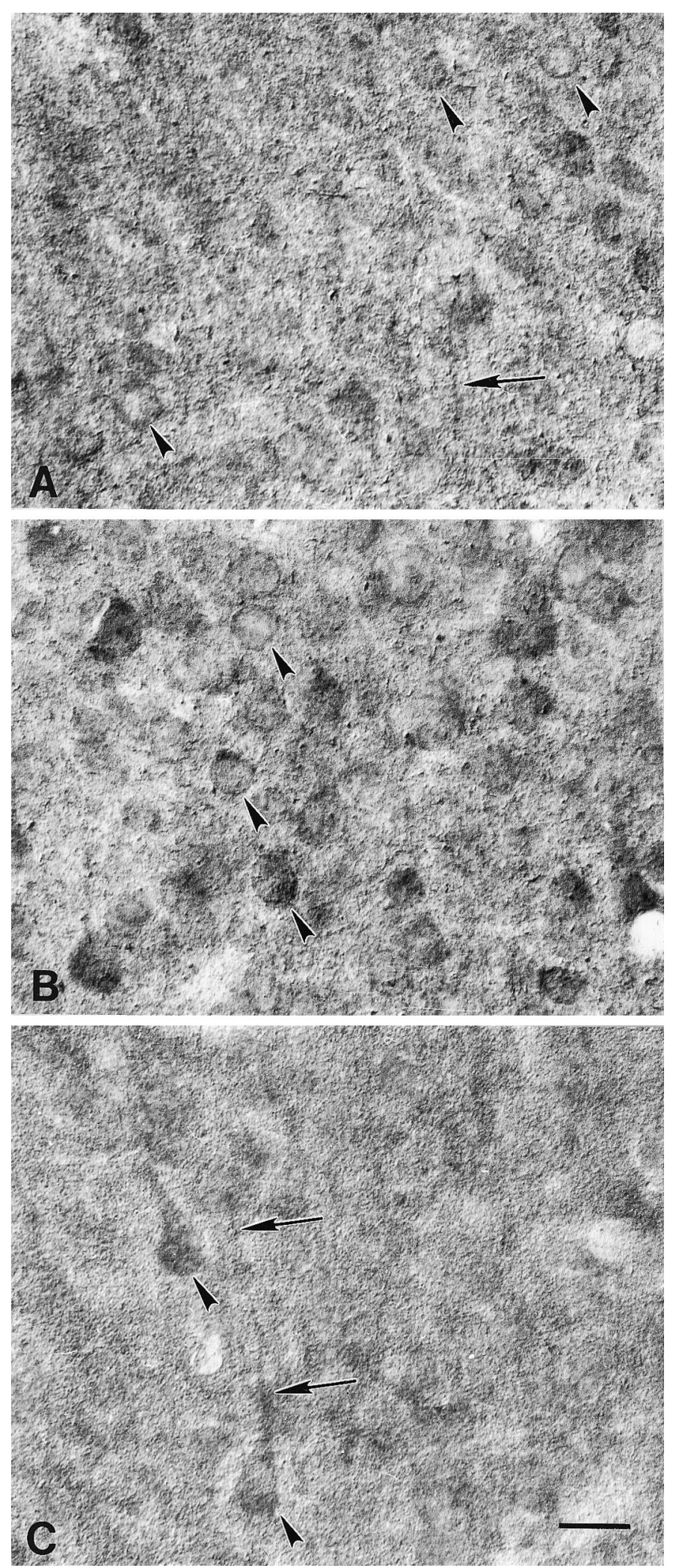

surface and cytoplasm was less prominent in this layer. Layer V subunit immunostaining was associated mainly with puncta scattered throughout the neuropil, whereas layer VI subunit immunostaining was characterized by high densities of cell surface and cytoplasmic immunoreactivity, as well as scatter puncta.

The density of immunostained punctate profiles was decreased in tissue fixed with glutaraldehyde, whereas cytoplasmic immunostaining was significantly increased. All specific immunoreactivity was eliminated by either omitting the primary antibody or substituting normal rabbit serum for the primary antibody.

\section{Compartmental distribution}

In tangential sections through layers II-III, intense immunoreactivity for GluR1, GluR2/3/4c, and GluR4 subunits was distributed in periodic patches that measured $150 \times 250 \mu \mathrm{m}$ with a centerto-center spacing of 400-600 $\mu \mathrm{m}$ (Fig. 5). Comparison of the immunostaining for each subunit with the histochemical stain $\mathrm{CO}$ (Fig. 5A) showed that immunostained patches corresponded to $\mathrm{CO}$-rich blobs. Within $\mathrm{CO}$ blob regions, scattered immunoreactive punctate profiles, as well as puncta surrounding somata, appeared to be larger and/or more intensely stained than the profiles in the surrounding interblob regions. The resolution was such that it could not be determined whether an increase in the overall density of punctate profiles also contributed to the increase in immunostaining.

Periodic patches of immunostaining for GluR2/3/4c subunits corresponding to stripes of CO-rich blobs were also evident in layers V and VI (Fig. 6). Immunoreactive puncta and cytoplasmic staining appeared to be larger and/or more intense in CO-rich blob regions than profiles found in the surrounding interblob regions.

In layer IVA, GluR1, GluR2/3/4c, and GluR4 immunostaining formed a lattice consisting of intensely stained walls surrounding lacunae of less intense immunostaining (Figs. $7 A, 8$ ). The $\mathrm{CO}$ staining in an adjacent section revealed a similar lattice, in which intensely stained walls surrounded weakly stained lacunae (Fig. $7 B$ ). Direct comparison by aligning the same radial blood vessels confirmed that the CO-stained and subunit-immunostained walls occupied the same regions. Puncta within the walls were often larger (GluR1 and GluR2/3/4c) and more intensely stained (GluR1, GluR2/3/4c, and GluR4) than puncta within the lacunae. Cells either exhibiting cytoplasmic GluR2/3/4c immunoreactivity or outlined with puncta immunoreactive for GluR1 and GluR2/ $3 / 4 \mathrm{c}$ were prominent in the lacunae but not apparent in the walls of the honeycomb.

$\leftarrow$

Figure 3. Details of AMPA subunit immunoreactivity in layers II-III of the macaque primary visual cortex. Differential interference contrast photomicrographs of GluR1 $(A)$, GluR2/3/4c $(B)$, and GluR4 $(C)$ immunostaining in sagittal sections through layers II-III. $A$, GluR1immunoreactive puncta vary in size and intensity and are scattered mainly throughout the neuropil; however, some of the puncta form short radial arrays (arrow) along what are presumably dendritic processes. Many of the somata display moderate levels of cell surface immunostaining (arrowheads). B, GluR2/3/4c immunostaining consists of a mixture of fine and coarse puncta that vary in staining intensity. Compared with GluR1 immunostaining, more of the puncta are coarse and intensely stained. Many of the somata display intense cell surface immunostaining (arrowheads). C, Lightly labeled GluR4-immunostained puncta are homogeneously distributed throughout the neuropil. The cell surface of a small number of pyramidal somata (arrowheads) and their apical dendrites (arrows) are labeled with puncta. Scale bar, $25 \mu \mathrm{m}$. 

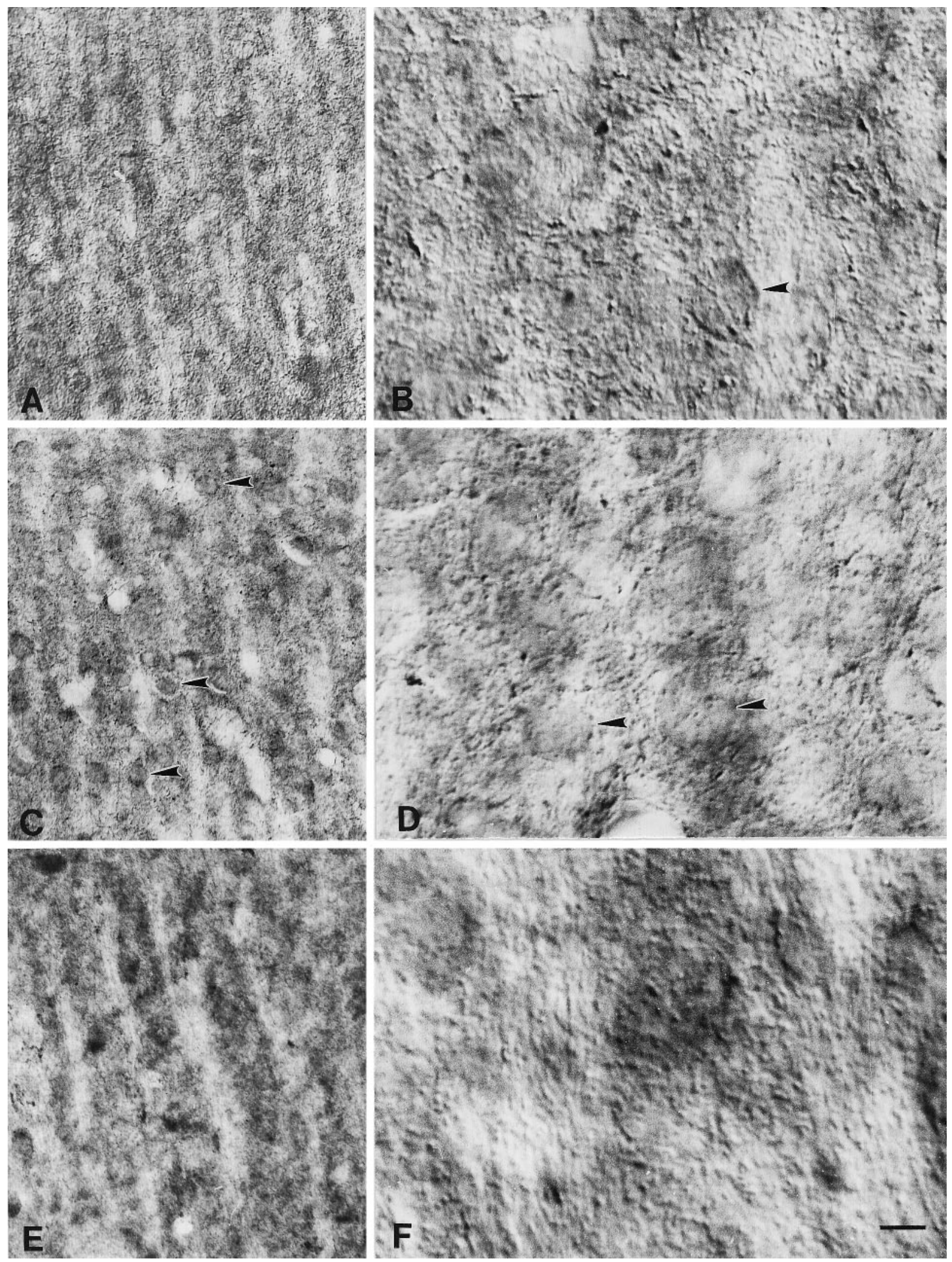

Figure 4. Details of AMPA subunit immunoreactivity in layer IVC of the macaque primary visual cortex. Differential interference contrast photomicrographs of GluR1 $(A, B)$, GluR2/3/4c $(C, D)$, and GluR4 $(E, F)$ immunostaining in sagittal sections through layer IVC. Intense immunostaining for each of the subunits is present in elongated stripes $(A, C, E) . B, D, F$, High-magnification photomicrographs reveal that the stripes of intense staining are composed of puncta that vary in size and intensity. GluR1 $(A, B)$ and GluR4 $(E, F)$ cell surface immunoreactivity $($ arrowheads) is variable, with some cells displaying very little immunoreactivity and others densely outlined. In comparison, many of the somata display moderate levels of cell surface immunostaining for GluR2/3/4c. Scale bars: $20 \mu \mathrm{m}$ in $A, C$, and $E ; 5 \mu \mathrm{m}$ in $B, D$, and $F$. 

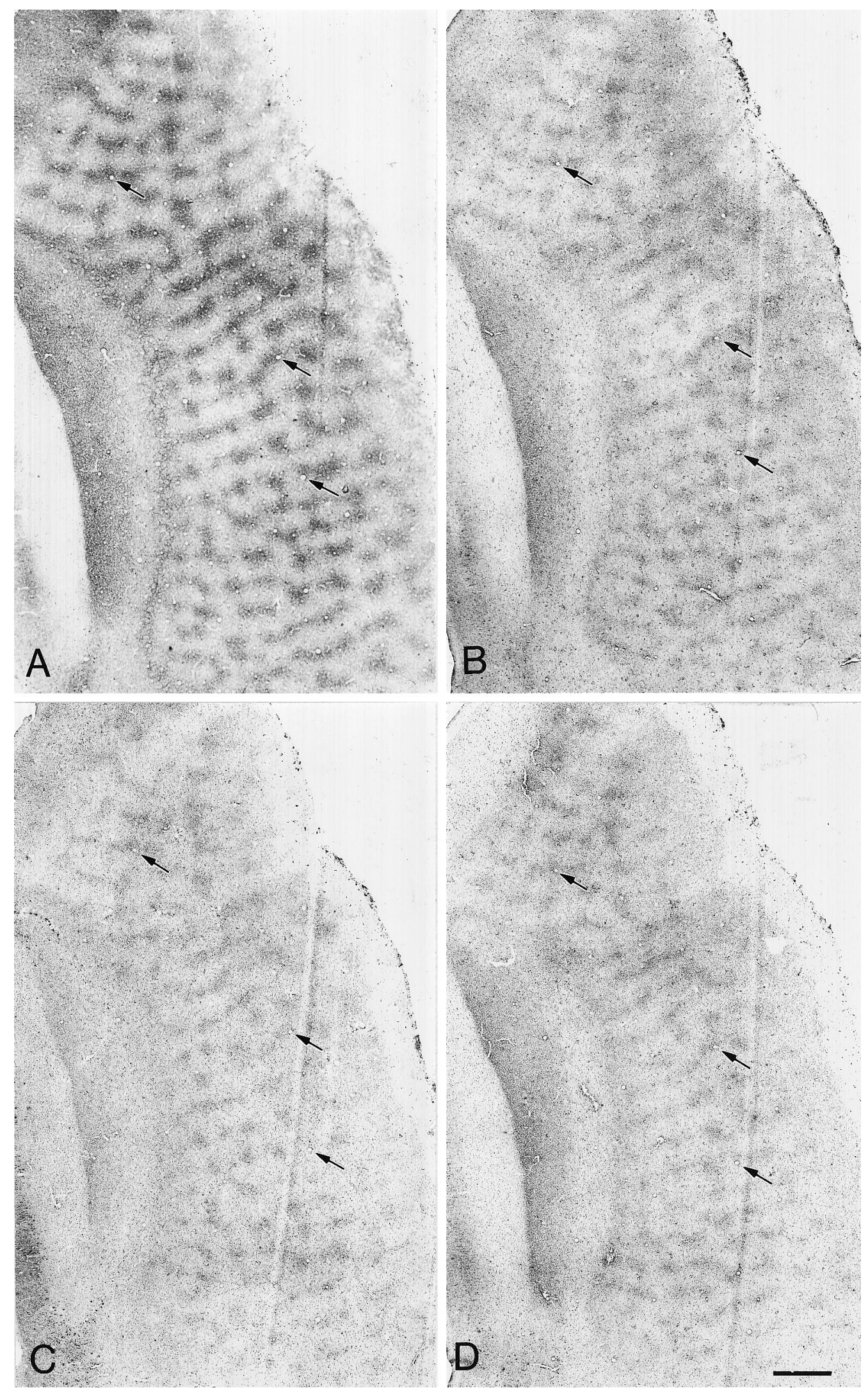

Figure 5. Compartmental distribution of immunostaining for GluR1, GluR2/3/4c, and GluR4 subunits in layers II-III. Photomicrographs of tangentially cut sections stained immunocytochemically for GluR1 $(B)$, GluR2/3/4c $(C)$, and GluR4 $(D)$ and histochemically for cytochrome oxidase $(A)$. Patches of intense immunostaining for GluR 1, GluR2/34c, and GluR4 are evident throughout layers II-III. Blobs of intense CO staining are apparent in the adjacent section. Comparing immunostained and CO-stained sections by aligning the same blood vessel profiles (arrows) shows that the immunostained patches coincide with the CO-stained blobs. Scale bar, $1 \mathrm{~mm}$. 


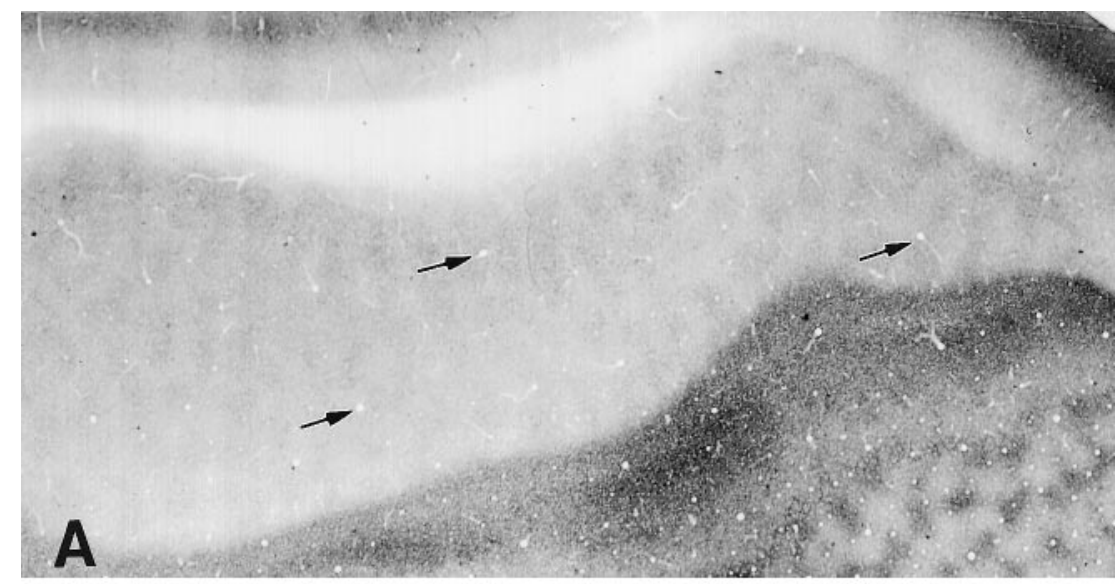

Figure 6. Compartmental distribution of immunostaining for GluR2/3/4c subunits in layers V-VI. Photomicrographs of tangentially cut sections stained immunocytochemically for GluR2/3/4c $(B)$ and histochemically for cytochrome oxidase $(A)$. Stripes of intense immunostaining for GluR $2 / 3 / 4 \mathrm{c}$ alternate with stripes of light immunostaining throughout layers V-VI. Blobs of intense CO staining forming regularly spaced rows are apparent in layers V-VI of an adjacent section. Comparison of immunostained and CO-stained sections by aligning the same blood vessel profiles (arrows) shows that the immunostained stripes coincide with the $\mathrm{CO}$-stained rows of blobs. $C$, High-magnification photomicrograph of a border between two intensely stained stripes and a lightly immunostained stripe (arrowheads bracket the lightly immunostained stripe). Within the intensely immunostained stripes, both cells and clusters of puncta are more intensely stained than those found in the lightly immunostained stripes. Scale bars: $1 \mathrm{~mm}$ in $A$ and $B ; 130 \mu \mathrm{m}$ in $C$.
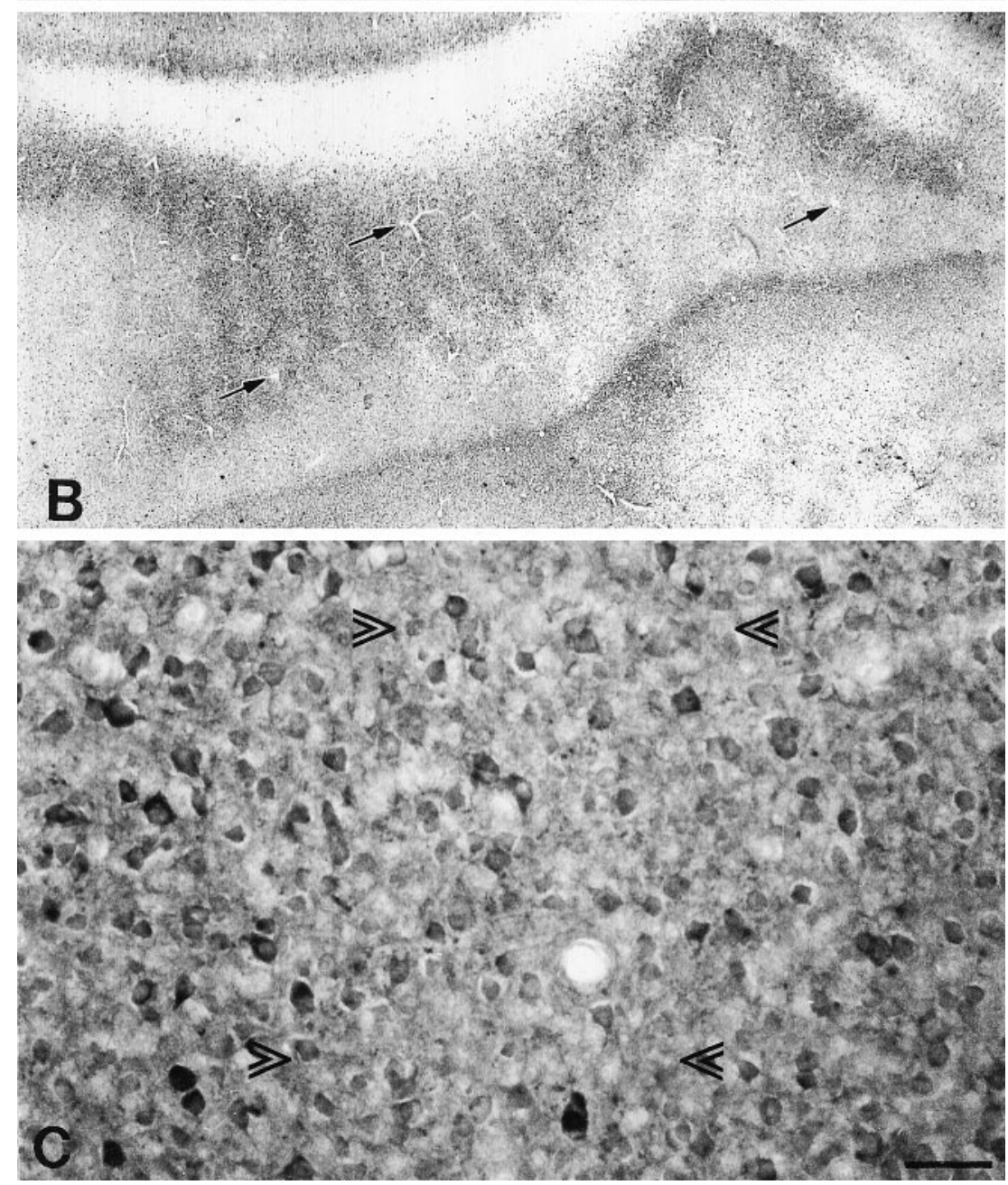

\section{DISCUSSION}

\section{Specificity of subunit immunostaining}

An important issue for interpreting the patterns of AMPA subunit immunoreactivity is the identity of the immunostained elements. Several lines of evidence suggest that the extremely rich immunostaining of fine punctate profiles observed throughout the neuropil represents synaptic and extrasynaptic AMPA receptors. Glutamate receptor subunits have been shown to form aggregates that are enriched in synaptic membranes (Wenthold et al., 1990, 1992; Rogers et al., 1991; Blackstone et al., 1992; Hullebroeck and
Hampson, 1992). These subunits cluster at specific postsynaptic sites (Craig et al., 1993) that correspond to hot spots of functional AMPA receptor activity (Bekkers and Stevens, 1989; Jones and Baughman, 1991). Extrasynaptic receptors have also been identified using high-resolution subunit localization and outside-out patch-clamp recordings of glutamate-gated channels in the soma and dendrites of both neurons and glia (Jones and Baughman, 1991; Hestrin, 1993; Martin et al., 1993a,b; Molnár et al., 1993; Baude et al., 1994). The present findings now demonstrate anatomical localization of the subunits that form AMPA receptors. 

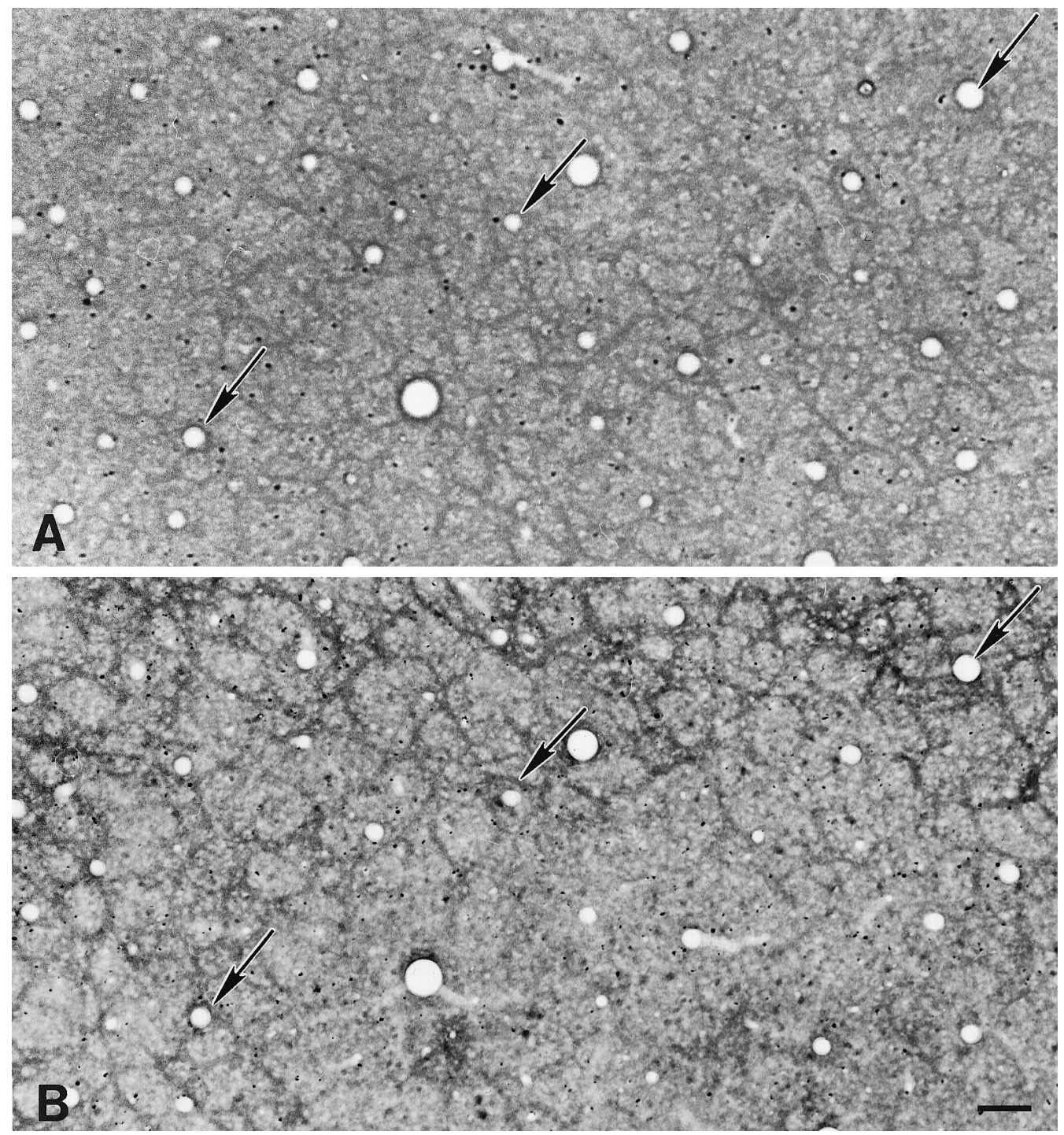

Figure 7. Comparison of immunostaining for the GluR1 subunit and $\mathrm{CO}$ in layer IVA. Photomicrographs of tangentially cut sections stained immunocytochemically for GluR1 $(A)$ and histochemically for $\mathrm{CO}(B)$. GluR1 immunostaining is characterized by an irregular lattice made up of intensely stained walls that surround lightly stained lacunae $(A)$. This irregular lattice is very similar to that seen with CO staining $(B)$. By aligning the same blood vessel profiles (arrows), it becomes apparent that the immunostained lattice overlaps with the CO-stained lattice. Scale bar, $100 \mu \mathrm{m}$.

Immunostaining consists of discrete puncta scattered throughout the neuropil, as well as along the surface of somata. Although the precise subcellular localization of AMPA subunits requires further characterization, immunoelectron microscopy using the same or similar antibodies has confirmed that subunit immunolabeling is present in postsynaptic densities of rat (Petralia and Wenthold, 1992; Martin et al., 1993b; Molnár et al., 1993; Baude et al., 1994; Phend et al., 1995) and primate (Martin et al., 1993a; our unpublished observations). Taken together, these data strongly suggest that the immunocytochemical methods used in this study recognize preferentially AMPA subunits that are assembled into receptors.

These results contrast with previous light microscopic studies using the same antibodies in which subunit immunostaining was preferentially localized to intracellular compartments of pyramidal cell somata and proximal apical dendrites (Petralia and Wenthold, 1992; Martin et al., 1993a,b; Vickers et al., 1993; Conti et al., 1994). The intracellular accumulation of reaction product could be related to various stages of synthesis, transport, assembly, and degradation of receptor subunits, but not to the number or location of actually expressed receptor molecules. $\mathrm{GABA}_{\mathrm{A}}$ receptor subunit studies demonstrate that the level of intracellular immunoreactivity may not be well correlated with levels of immunoreactivity on the plasma membrane (Somogyi, 1989). Technical issues may explain the differences observed in subunit protein localization. Although the presence of glutaraldehyde, high percentage of paraformaldehyde, and lengthy perfusion times may preserve more labile cytoplasmic pools, they can also produce excessive cross-linking, resulting in the failure of the antiserum to reach antigenic sites (Griffiths, 1993). The limited punctate immunolabeling reported in previous studies could be attributed to steric hindrance of epitopes associated with synaptic membrane. Increased levels of cytoplasmic immunostaining and decreased levels of immunostained puncta were also observed in glutaraldehyde-processed tissue in the current study.

\section{AMPA subunit organization in macaque $\mathbf{V 1}$}

A striking result was the marked variability in the density of AMPA subunit immunoreactivity across layers and compartments 

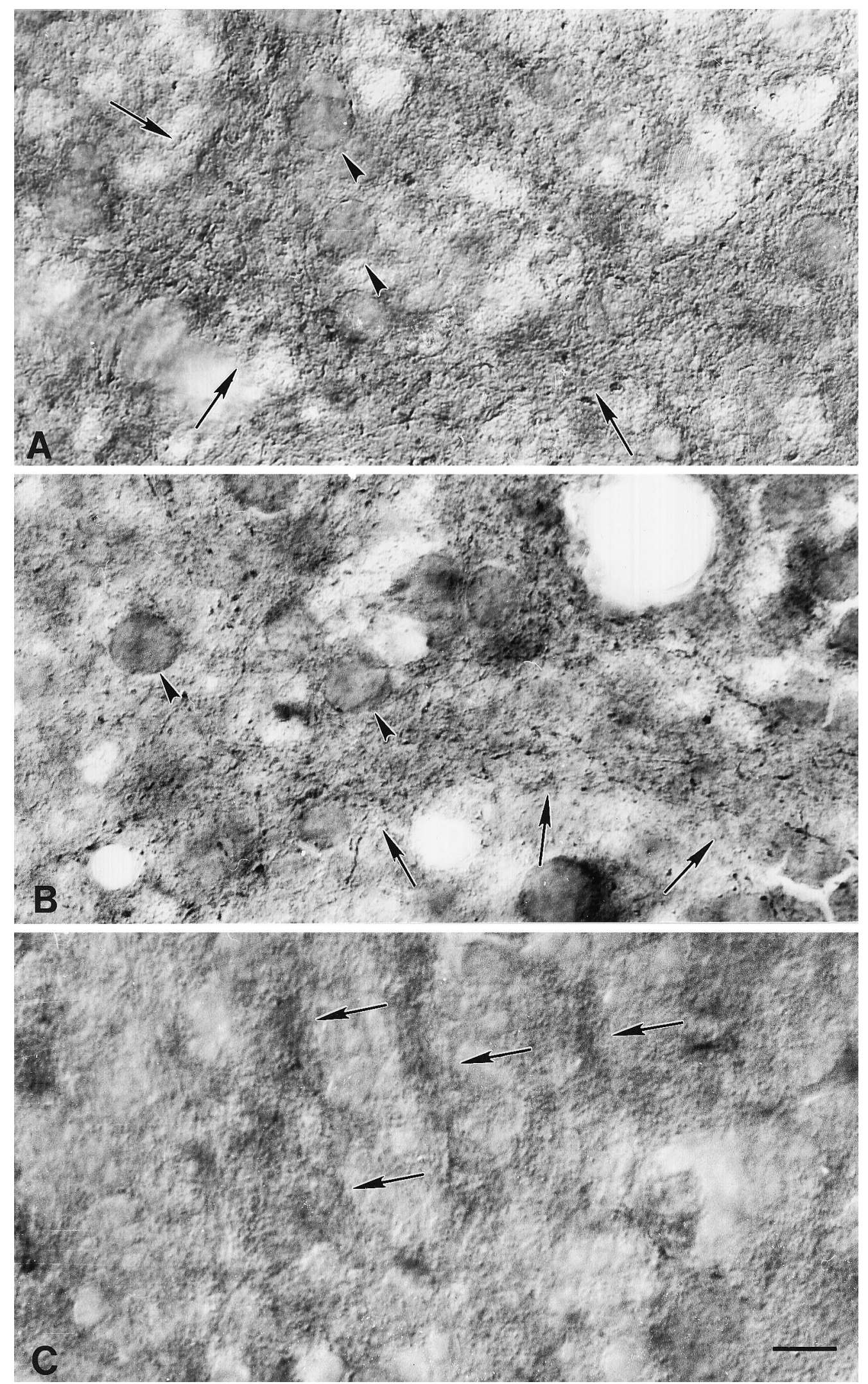

Figure 8. Compartmental distribution of immunostaining for the GluR1, GluR2/3/4c, and GluR4 subunits in layer IVA. High-magnification photomicrographs of tangentially cut sections stained immunocytochemically for GluR $1(A)$, GluR 2/3/4c (B), and an oblique section stained for GluR4 $(C)$. Subunit immunostaining is characterized by an irregular lattice made up of intensely stained walls (arrows) that surround lightly stained lacunae. A greater density of immunostained puncta is evident in the lattice compared with the lightly stained lacunae. Somata (arrowheads) found at the edges of the walls and in the lightly stained lacunae are surrounded by GluR1- and GluR2/3/4c-immunostained puncta. Cells in the lacunae often contain GluR2/3/4c cytoplasmic staining. Scale bar, $10 \mu \mathrm{m}$. 
of macaque V1. Assuming that intensity of immunostaining is directly related to subunit density leads to the prediction that AMPA subunit immunostaining would follow the distribution of asymmetric or excitatory synapses in macaque V1. This was not the case, however, as immunostaining was more intense in the CO-rich blobs of layers II-III than in surrounding interblobs, even though these two compartments contain the same density of asymmetric synapses (Beaulieu et al., 1992). Immunostaining was more intense in layers IVC and VI than other cortical layers, even though these two layers contain significantly less asymmetrical synapses (Beaulieu et al., 1992). These qualitative differences in the present study cannot be explained by limited subunit recognition, because the antibodies used recognize the majority of AMPA subunits known to be expressed in the CNS (Hollmann and Heinemann, 1994). One explanation for the current results is that the number of AMPA receptors differs at individual synapses. This hypothesis is supported by anatomical and physiological evidence demonstrating that the density of subunit immunostaining (Nusser et al., 1994; Siegel et al., 1994) and the ratio of AMPA/kainate to NMDA receptors (Huettner and Baughman, 1988; Stern et al., 1992; Thomson and Deuchars, 1994) varies at different synapses.

The distribution of AMPA subunits observed in these experiments strongly suggests that thalamocortical synapses may preferentially express a high density of AMPA receptors. The intense immunostained puncta in layer IVA forms a pattern identical to that observed with CO staining (Livingstone and Hubel, 1982; Horton, 1984), to the distribution of geniculocortical axon terminals (Hendrickson et al., 1978; Livingstone and Hubel, 1982; Blasdel and Lund, 1983; Itaya et al., 1984), and to the organization of horizontally aligned, thin dendrites that surround cones of neurons (Peters and Sethares, 1991). Similarly, the intense immunostained puncta in layer IVC forms a pattern of alternating intensely stained stripes and poorly stained stripes that can be related to geniculocortical afferent terminations (Hubel and Wiesel, 1972; Hendrickson et al., 1978; DeFelipe and Jones, 1991), clusters of dendrites (Peters and Sethares, 1991), and glutamate immunoreactive processes (Carder and Hendry, 1994). This hypothesis is also supported by a large body of literature indicating that excitatory neurotransmission at thalamocortical synapses is primarily mediated by AMPA receptors (Hagihara et al., 1988; Shirokawa et al., 1989; Fox et al., 1989, 1992; Nishigori et al., 1990; Gil and Amitai, 1996). Despite the fact that geniculocortical afferent terminals may represent less than $20 \%$ of the asymmetrical synapses in layer IVC (Garey and Powell, 1971; Tigges and Tigges, 1979; Peters et al., 1994), physiological evidence indicates that thalamic input plays an essential role in driving cortical cells (Tanaka, 1983; Ferster et al., 1996). These data suggest that the strength of a connection may depend on diverse mechanisms, such as the large size of thalamic synapses and increased concentration of AMPA receptors, rather than the number of synapses formed by a pathway. Preliminary electron microscopic evidence indicating that thalamocortical synapses express a higher density of AMPA subunits than corticocortical synapses provides support for this idea (Weinberg and Kharazia, 1996) (R. Weinberg, personal communication).

Other synaptic and extrasynaptic receptors also might contribute to the observed staining pattern. The relative contribution of AMPA and NMDA receptors at the majority of excitatory synapses in layer IVC is unknown. Excitatory synapses onto GABAimmunopositive postsynaptic neuronal elements are mediated primarily by AMPA receptors (Thomson and Deuchars, 1994).
Although inhibitory interneurons are preferentially distributed in geniculocortical recipient layers, excitatory synapses onto inhibitory interneurons are not (Beaulieu et al., 1992). Although there is considerable evidence that subunit expression is related to cell type (Vickers et al., 1993; Bochet et al., 1994; Jonas et al., 1994; Geiger et al., 1995), the pattern of subunit immunostaining observed in the present study does not correspond to the numerical densities of neurons, astrocytes, oligodendrocytes, and microcytes (O'Kusky and Colonnier, 1982). However, there is widespread evidence that receptor expression is influenced by local environmental cues (Gall et al., 1990; Pasqualotto et al., 1993; Audinat et al., 1994; Bessho et al., 1994; DeFelipe et al., 1994; Kamphuis et al., 1994; Kraus et al., 1994; Perez-Velazquez and Zhang, 1994; Ehlers et al., 1995). Thus, synaptic and/or extrasynaptic expression of AMPA receptors may also be influenced by the milieu of particular layers and compartments, rather than being solely determined by cell type.

\section{Differences in AMPA subunit distributions}

Although results from the present study are in agreement with physiological studies demonstrating the predominant use of AMPA receptors in layers receiving geniculocortical afferents, radioligand binding studies report low levels of binding in these same layers (Shaw and Cynader, 1986). Variations in AMPA subunit composition might be important for explaining this inconsistency. Homeric AMPA receptors are activated by kainate and to a lesser extent by AMPA, yet exhibit high-affinity $\left[{ }^{3} \mathrm{H}\right] \mathrm{AMPA}$ but not $\left[{ }^{3} \mathrm{H}\right]$ kainate binding sites (Boulter et al., 1990; Keinänen et al., 1990; Hollmann et al., 1991). Heteromeric AMPA receptors generally show larger current amplitudes but lower potencies than homomeric receptors (Boulter et al., 1990, Nakanishi et al., 1990). Subunit interaction may exacerbate these discrepancies between the pharmacological properties and the physiological response (Boulter et al., 1990; Nakanishi et al., 1990; Sakimura et al., 1990). The technical difficulty of measuring tritiated ligand binding at the very low affinity levels that are sufficient to produce electrophysiological responses in heteromeric receptors, along with the greater sensitivity of immunocytochemical methods, may partly explain the low levels of receptor binding and high levels of subunit immunostaining in layer IVC.

Subtle differences in the laminar, tangential, and subcellular localization of the receptor subunits suggest that both synaptic and extrasynaptic AMPA receptors found in V1 represent heterogeneous populations. It is assumed that where these differences exist the physiological and pharmacological properties of the AMPA receptors will vary. Studies correlating the functional properties of AMPA receptors with the specific mRNA at the single-cell level indicate that expression of GluR2 determines the formation of receptors with relatively slow gating properties and high calcium permeability, whereas the GluR1 and GluR4 subunits promote assembly of more rapidly gated receptors with low calcium permeability (Bochet et al., 1994; Jonas et al., 1994; Geiger et al., 1995). From the results of the present study, it could be argued that cells in the $\mathrm{CO}$ blobs of layers V-VI express greater densities of GluR2/3/4c than cells in the interblobs and are therefore more likely to express slow AMPA receptors with little calcium permeability. Even in layers and compartments in which each of the subunits is densely expressed, differences in AMPA receptors are still likely to exist. For example, GluR1immunostained puncta in the walls of the IVA lattice are densely distributed and homogeneously expressed compared with the nonuniform distribution of large, intensely GluR2/3/4c- 
immunostained puncta in this same compartment. These data suggest that a large portion of the AMPA receptors in the walls of the IVA lattice is composed of the GluR1 subunit, whereas a smaller subset is composed of predominantly the GluR2/3/4c subunit. GluR2/3/4c immunostaining is also more prominent along the cell surface of pyramidal neurons than GluR1 and GluR4 immunostaining, suggesting that the functional properties of AMPA receptors in the postsynaptic membrane could differ from those in the somatic membrane patches.

The physiological importance of AMPA receptor differences remains elusive. First, the repercussions of certain channel properties are unknown. For example, it remains to be shown whether the additional route of synaptically mediated $\mathrm{Ca}^{2+}$ entry may be linked to an increase in synaptic efficacy. Alternatively, $\mathrm{Ca}^{2+}$ entry through AMPA receptors could activate $\mathrm{Ca}^{2+}$-dependent $\mathrm{K}^{+}$ channels or could lead to the inactivation of NMDA receptors (Medina et al., 1994). Second, although differences in the relative proportions of distinct subunits across the cortical layers indicate unique pharmacological, kinetic, and gating characteristics of AMPA receptors in each layer, the physiological relevance of the expression of specific AMPA receptor subtypes is dependent on its cellular and subcellular localization. Thus, activation of a particular receptor subtype will lead to different functional consequences depending on where the receptor is operating.

\section{REFERENCES}

Audinat E, Lambolez B, Rossier J, Crepel F (1994) Activity-dependent regulation of $N$-methyl-D-aspartate receptor subunit expression in rat cerebellar granule cells. Eur J Neurosci 6:1792-1800.

Baude A, Molnár E, Latawiec D, McIlhinney J, Somogyi P (1994) Synaptic and nonsynaptic localization of the GluR1 subunit of the AMPAtype excitatory amino acid receptor in the rat cerebellum. J Neurosci 14:2830-2843.

Beaulieu C, Kisvarday Z, Somogyi P, Cynader M, Cowey A (1992) Quantitative distribution of GABA-immunonegative neurons and synapses in the monkey striate cortex (area 17). Cereb Cortex 2:295-309.

Bekkers JM, Stevens CF (1989) NMDA and non-NMDA receptors are co-localized at individual excitatory synapses in cultured rat hippocampus. Nature 341:230-233.

Bessho Y, Nawa H, Nakanishi S (1994) Selective up-regulation of an NMDA receptor subunit mRNA in cultured cerebellar granule cells by $\mathrm{K}^{+}$-induced depolarization and NMDA treatment. Neuron 12:87-95.

Blackstone CD, Moss SJ, Martin LJ, Levey AI, Price DL, Huganir RL (1992) Biochemical characterization and localization of a non- $N$ methyl-D-aspartate glutamate receptor in rat brain. J Neurochem 58:1118-1126.

Blasdel GG, Lund JS (1983) Termination of afferent axons in macaque striate cortex. J Neurosci 3:1389-1413.

Bochet P, Audinat E, Lambolez B, Crepel F, Rossier J, Iino M, Tsuzuki K, Ozawa S (1994) Subunit composition at the single-cell level explains functional properties of a glutamate-gated channel. Neuron 12:383-388.

Boulter J, Hollmann M, O'Shea-Greenfield A, Hartley M, Deneris E, Maron C, Heinemann S (1990) Molecular cloning and functional expression of glutamate receptor subunit genes. Science 249:1033-1037.

Carder RK, Hendry SHC (1994) Neuronal characterization, compartmental distribution and activity-dependent regulation of glutamate immunoreactivity in adult monkey striate cortex. J Neurosci 14:242-262.

Collingridge GL, Lester RA (1989) Excitatory amino acids in the vertebrate central nervous system. Pharmacol Rev 40:143-210.

Colquhoun D, Jonas P, Sakmann B (1992) Action of brief pulses of glutamate on AMPA/kainate receptors in patches from different neurones of rat hippocampal slices. J Physiol (Lond) 458:261-287.

Conti F, Minelli A, Brecha NC (1994) Cellular localization and laminar distribution of AMPA glutamate receptor subunit mRNAs and proteins in the rat cerebral cortex. J Comp Neurol 350:241-259.

Craig AM, Blackstone CD, Huganir RL, Banker G (1993) The distribution of glutamate receptors in cultured rat hippocampal neurons: postsynaptic clustering of AMPA-selective subunits. Neuron 10:1055-1068.

DeFelipe J, Jones EG (1991) Parvalbumin immunoreactivity reveals layer IV of monkey cerebral cortex as a mosaic of microzones of thalamic afferent terminations. Brain Res 562:39-47.

DeFelipe J, Huntley GW, del Rio MR, Sola RG, Morrison JH (1994) Microzonal decreases in the immunostaining for non-NMDA iontotropic excitatory amino acid receptor subunits GluR 2/3 and GluR 5/6/7 in human epileptogenic neocortex. Brain Res 657:150-158.

Ehlers MD, Whittemore GT, Huganir RL (1995) Regulated subcellular distribution of the NR1 subunit of the NMDA receptor. Science 269:1734-1737.

Ferster D, Chung S, Wheat H (1996) Orientation selectivity of thalamic input to simple cells of cat visual cortex. Nature 380:249-252.

Fox K, Sato H, Daw N (1989) The location and function of NMDA receptors in cat and kitten visual cortex. J Neurosci 9:2443-2454.

Fox K, Daw N, Sato H, Czepita D (1992) The effect of visual experience on development of NMDA receptor synaptic transmission in kitten visual cortex. J Neurosci 12:2672-2684.

Freund TF, Martin KAC, Soltesz I, Somogyi P, Whitteridge D (1989) Arborization pattern and postsynaptic targets of physiologically identified thalamocortical afferents in striate cortex of the macaque monkey. J Comp Neurol 289:315-386.

Gall C, Sumikawa K, Lynch G (1990) Levels of mRNA for a putative kainate receptor are affected by seizures. Proc Natl Acad Sci USA 87:7643-7647.

Garey LJ, Powell TPS (1971) An experimental study of the termination of the lateral geniculo-cortical pathway in the cat and monkey. Proc R Soc Lond [Biol] 179:41-63.

Geiger JRP, Melcher T, Koh D-S, Sakmann B, Seeburg PH, Jonas P, Monyer H (1995) Relative abundance of subunit mRNAs determines gating and $\mathrm{Ca}^{+}$permeability of AMPA receptors in principal neurons and interneurons in rat CNS. Neuron 15:193-204.

Gil Z, Amitai Y (1996) Adult thalamocortical transmission involves both NMDA and non-NMDA receptors. J Neurophysiol 76:2547-2554.

Griffiths G (1993) Fine structure immunocytochemistry. New York: Springer.

Hagihara K, Tsumoto T, Sato H, Hata Y (1988) Actions of excitatory amino acid antagonists on geniculocortical transmission in the cat's visual cortex. Exp Brain Res 69:407-416.

Hendrickson AE, Wilson JR, Ogren MP (1978) The neuroanatomical organization of pathways between the dorsal lateral geniculate nucleus and visual cortex in old and new world primates. J Comp Neurol 182:123-136.

Hendry SHC, Yoshioka T (1994) A neurochemically distinct third channel in the macaque dorsal lateral geniculate nucleus. Science 264:575-577.

Hestrin S (1993) Different glutamate-receptor-channels mediate fast excitatory synaptic currents in inhibitory and excitatory cortical neurons. Neuron 11:1083-1091.

Hollmann M, Heinemann S (1994) Cloned glutamate receptors. Annu Rev Neurosci 17:31-108.

Hollmann M, O'Shea-Greenfield A, Rogers SW, Heinemann S (1989) Cloning by functional expression of a member of the glutamate receptor family. Nature 342:643-648.

Hollmann M, Hartley M, Heinemann S (1991) $\mathrm{Ca}^{2+}$ permeability of KA-AMPA-gated glutamate receptor channels depends on subunit composition. Science 252:851-853.

Horton JC (1984) Cytochrome oxidase patches: a new cytoarchitectonic feature of monkey visual cortex. Philos Trans R Soc Lond Ser B 304:199-253.

Hubel DH, Wiesel TN (1972) Laminar and columnar distribution of geniculo-cortical fibers in the macaque monkey. J Comp Neurol 146:421-450.

Huettner JE, Baughman RW (1988) The pharmacology of synapses formed by identified corticocollicular neurons in primary cultures of rat visual cortex. J Neurosci 8:160-175.

Hullebroeck MF, Hampson DR (1992) Characterization of the oligosaccharide side chains on kainate binding proteins and AMPA receptors. Brain Res 590:187-192.

Itaya SK, Itaya PW, Van Hoesen GW (1984) Intracortical termination of the retino-geniculo-striate pathway studied with transsynaptic tracer wheat germ agglutinin-horseradish peroxidase and cytochrome oxidase staining in the macaque monkey. Brain Res 304:303-310.

Jonas P, Racca C, Sakmann B, Seeburg PH (1994) Differences in Ca2 ${ }^{+}$ permeability of AMPA-type glutamate receptor channels in neocortical neurons caused by differential GluR-B subunit expression. Neuron 12:1281-1289. 
Jones KA, Baughman RW (1991) Both NMDA and non-NMDA subtypes of glutamate receptors are concentrated at synapses on cerebral cortical neurons in culture. Neuron 7:593-603.

Kamphuis W, De Rijk TC, Talamini LM, Lopes da Silva FH (1994) Rat hippocampal kindling induces changes in the glutamate receptor mRNA expression patterns in dentate granule neurons. Eur J Neurosci 6:1119-1127.

Keinänen K, Wisden W, Sommer B, Werner P, Herb A, Verdoorn TA, Sakmann B, Seeburg PH (1990) A family of AMPA-selective glutamate receptors. Science 249:556-560.

Koh D-S, Geiger JRP, Jonas P, Sakmann B (1995) $\mathrm{Ca}^{2+}$-permeable AMPA and NMDA receptor channels in basket cells of rat hippocampal dentate gyrus. J Physiol (Lond) 485:383-402.

Kraus JE, Yeh G-C, Bonhaus DW, Nadler JV, McNamara JO (1994) Kindling induces the long-lasting expression of a novel population of NMDA receptors in hippocampal region CA3. J Neurosci 14:4196-4205.

Livingstone MS, Hubel DH (1982) Thalamic input to cytochrome oxidase-rich regions in monkey visual cortex. Proc Natl Acad Sci USA 79:6098-6101.

Livsey CT, Costa E, Vicini S (1993) Glutamate-activated currents in outside-out patches from spiny versus aspiny neurons of rat hippocampal slices. J Neurosci 13:5324-5333.

Martin LJ, Blackstone CD, Levey AI, Huganir RL, Price DL (1993a) Cellular localizations of AMPA glutamate receptors within the basal forebrain magnocellular complex of rat and monkey. J Neurosci 13:2249-2263.

Martin LJ, Blackstone CD, Levey AI, Huganir RL, Price DL (1993b) AMPA glutamate receptor subunits are differentially distributed in rat brain. Neuroscience 53:327-358.

Medina I, Filippova N, Barbin G, Ben-Ari Y, Bregestovski P (1994) Kainate-induced inactivation of NMDA currents via an elevation of intracellular $\mathrm{Ca}^{2+}$ in hippocampal neurons. J Neurophysiol 72:456-465.

Molnár E, Baude A, Richmond SA, Patel PB, Somogyi P, McIlhinney RAJ (1993) Biochemical and immunocytochemical characterization of antipeptide antibodies to a cloned GluR1 glutamate receptor subunit: cellular and subcellular distribution in the rat forebrain. Neuroscience 53:307-326.

Monaghan DT, Bridges RJ, Cotman CW (1989) The excitatory amino acid receptors: their classes, pharmacology, and distinct properties in the function of the central nervous system. Annu Rev Pharmacol Toxicol 29:365-402.

Nakanishi N, Shneider NA, Axel R (1990) A family of glutamate receptor genes: evidence for the formation of heteromultimeric receptors with distinct channel properties. Neuron 5:569-581.

Nishigori A, Tsumoto T, Kimura F (1990) Contribution of quisqualate/ kainate and NMDA receptors to excitatory synaptic transmission in the rat's visual cortex. Vis Neurosci 5:591-604.

Nusser Z, Mulvihill E, Streit P, Somogyi P (1994) Subsynaptic segregation of metabotropic and iontotropic glutamate receptors as revealed by immunogold localization. Neuroscience 61:421-427.

O'Kusky J, Colonnier M (1982) A laminar analysis of the number of neurons, glia, and synapses in the visual cortex (area 17) of adult macaque monkeys. J Comp Neurol 210:278-290.

Pasqualotto BA, Lanius RA, Shaw CA (1993) Regulation of $\mathrm{GABA}_{\mathrm{A}}$ and AMPA receptors by agonist and depolarizing stimulation requires phosphatase or kinase activity. NeuroReport 4:447-450.

Perez-Velazquez JL, Zhang L (1994) In vitro hypoxia induces expression of the NR2C subunit of the NMDA receptor in rat cortex and hippocampus. J Neurochem 63:1171-1173.

Peters A, Sethares C (1991) Organization of pyramidal neurons in area 17 of monkey visual cortex. J Comp Neurol 306:1-23.

Peters A, Payne BR, Budd J (1994) A numerical analysis of the geniculocortical input to striate cortex in the monkey. Cereb Cortex 4:215-229.
Petralia RS, Wenthold RJ (1992) Light and electron immunocytochemical localization of AMPA-selective glutamate receptors in the rat brain. J Comp Neurol 318:329-354.

Phend KD, Rustioni A, Weinberg RJ (1995) An osmium-free method of epon embedment that preserves both ultrastuctural and antigenicity for post-embedding immunocytochemistry. J Histochem Cytochem 43:283-292.

Rogers SW, Hughes TE, Hollmann M, Gasic GP, Deneris ES, Heinemann S (1991) The characterization and localization of the glutamate receptor subunit GluR1 in the rat brain. J Neurosci 11:2713-2724.

Sakimura K, Bujo H, Kushiya E, Araki K, Yamazaki M, Yamazaki M, Meguro H, Warashina A, Numa S, Mishina M (1990) Functional expression from cloned cDNAs of glutamate receptor species responsive to kainate and quisqualate. FEBS Lett 272:73-80.

Schoepp D, Bockaert J, Sladeczek F (1990) Pharmacological and functional characteristics of metabotropic excitatory amino acid receptors. Trends Pharmacol Sci 11:508-515.

Shaw C, Cynader M (1986) Laminar distribution of receptors in monkey (Macaca fascicularis) geniculostriate system. J Comp Neurol 248:301-312.

Shirokawa T, Nishigori A, Kimura F, Tsumoto T (1989) Actions of excitatory amino acid antagonists on synaptic potentials of layer II/III neurons of the cat's visual cortex. Exp Brain Res 78:489-500.

Siegel SJ, Janssen WG, Gasic GP, Jahn R, Heinemann SF, Morrison JH (1994) Regional, cellular, and ultrastructural distribution of $N$-methylD-aspartate receptor subunit in monkey hippocampus. Proc Natl Acad Sci USA 91:564-568.

Somogyi P (1989) Synaptic organization of GABAergic neurons and $\mathrm{GABA}_{\mathrm{A}}$ receptors in the lateral geniculate nucleus and visual cortex. In: Neural mechanisms of visual perception (Lam DK-T, Gilbert CD, eds), pp 35-62. Woodlands, TX: Portfolio.

Stern P, Edwards FA, Sakmann B (1992) Fast and slow components of unitary EPSCs on stellate cells elicited by focal stimulation in slices of rat visual cortex. J Physiol (Lond) 449:247-278.

Streit P (1984) Glutamate and aspartate as transmitter candidates for systems of the cerebral cortex. In: Cerebral cortex, Vol 2, Functional properties of cortical cells (Jones EG, Peters A, eds), pp 119-143. New York: Plenum.

Tanaka K (1983) Cross-correlation analysis of geniculostriate neuronal relationships in the cat. J Neurophysiol 49:1303-1318.

Thomson AM, Deuchars J (1994) Temporal and spatial properties of local circuits in neocortex. Trends Neurosci 17:119-126.

Tigges M, Tigges J (1979) Types of degenerating geniculocortical axon terminals and their contribution to layer IV of area 17 in the squirrel monkey (Saimiri). Cell Tissue Res 196:471-486.

Tsumoto T (1990) Excitatory amino acid transmitters and their receptors in neural circuits of the cerebral cortex. Neurosci Res 9:79-102.

Vickers JC, Huntley GW, Edwards AM, Moran T, Rogers SW, Heinemann SF, Morrison JH (1993) Quantitative localization of AMPA/ kainate and kainate glutamate receptor subunit immunoreactivity in neurochemically identified subpopulations of neurons in the prefrontal cortex of the macaque monkey. J Neurosci 13:2982-2992.

Weinberg RJ, Kharazia VN (1996) Excitatory amino acids in thalamocortical transmission. In: Excitatory amino acids and the cerebral cortex (Conti F, Hicks TP, eds), pp 109-120. Cambridge, MA: MIT.

Wenthold RJ, Hunter C, Wada K, Dechesne CJ (1990) Antibodies to a $C$-terminal peptide of the rat brain glutamate receptor subunit, GluR-A, recognize a subpopulation of AMPA binding sites but not kainate sites. FEBS Lett 276:147-150.

Wenthold RJ, Yokotani N, Doi K, Wada K (1992) Immunochemical characterization of the non-NMDA glutamate receptor using subunitspecific antibodies. J Biol Chem 267:501-507.

Wong-Riley MTT (1979) Changes in the visual system of monocularly sutured or enucleated cats demonstrable with cytochrome oxidase histochemistry. Brain Res 171:11-28. 